Spatial Causalities in Resource Rushes : Notes from the Finnish Mining Boom

Kröger, Markus

2016

Kröger , M 2016 , ' Spatial Causalities in Resource Rushes : Notes from the Finnish Mining pÿBoom ' , Journal of Agrarian Change , vol. 16 , no. 4 , pp. 543570 . https://doi.org/10.1111/joac.12113

http://hdl.handle.net/10138/231304

https://doi.org/10.1111/joac.12113

Downloaded from Helda, University of Helsinki institutional repository.

This is an electronic reprint of the original article.

This reprint may differ from the original in pagination and typographic detail.

Please cite the original version. 


\title{
Spatial Causalities in Resource Rushes: Notes from the Finnish Mining Boom Markus Kröger
}

\author{
Kröger, M . (2015), Spatial Causalities in Resource Rushes: Notes from the Finnish Mining Boom. Journal \\ of Agrarian Change. doi: 10.1111/joac.12113
}

Note: this is not the original or official version of the article. For the published version, please send an email to markus.kroger@gmail to ask for a copy, or go for a download to:

http:// onlinelibrary.wiley.com/ doi/10.1111/joac.12113/ full

Markus Kröger, Department of Social Research and Department of Political and Economic Studies, University of Helsinki, Unioninkatu 37, P.0. Box 54, 00014 University of Helsinki, Finland.

\begin{abstract}
Since the mid-2000s, the world has seen an unprecedented expansion in corporate resource extraction. This global phenomenon has not been restricted to the Global South, but has also been, unexpectedly and interestingly, felt in the Global North in contexts that were considered to be ruled by political systems where the impacts of rapid resource extraction would not be felt. Between 2005 and 2010, for example, the volume of metallic ore and waste rock mining in Finland increased from fewer than 5 million tons to 46 million tons, mostly through the inauguration of four large mines in the east and north of the country. This paper examines the various explanations for the mining expansion, based on expert interviews, participant observation and a spatial analysis of the change dynamics. The importance and causalities in the control and divisions of social, physical and symbolic spaces are assessed, drawing on and interweaving the theories of Arrighi and Harvey, and conceptualizations of M oore and Bourdieu. A series of fertile conceptual tools for analysing the role of spatial dynamics in land-use changes is developed and put to work in the empirical analysis. The results are significant for the literatures on spatial dynamics and Arctic land-use change.
\end{abstract}

Keywords: resource frontier; corporate resource exploitation; Arctic land rush; space; Bourdieu

I would like to thank the editors, the anonymous reviewers and all those interviewed for their time and for their extremely constructive comments. Research funding was provided by the Academy of Finland.

\section{Introduction}

Large-scale land transactions and landscape changes caused by developmental projects have increased substantially since 2005, especially in Asia and Latin America (World Bank 2010). Although there is considerable literature on this resource rush in the South (Edelman et al. 2013), the northernmost areas of the Global North, such as the Arctic, have not received attention. However, since 2007, interest in the Arctic country peripheries has increased substantially, as these areas have become a hotbed of developmental/industrial projects such as energy, mining, (eco)-tourism and transnational trade-route building, coupled with rising militarization and diplomatic efforts to govern the Arctic (Klare 2012). 1 The phenomenon links to a growing capitalism and/or foreignization in peripheral regions, including the Arctic Chinese investments in Icelandic ports and other battles to grab global trade routes provide examples - 
wherein spaces formerly under the control of the home nation or local community, such as mining areas, are being brought under foreign and/or capitalist control.

The current global historical conjunction is one wherein resources are becoming harder to obtain, exemplified by the Arctic resource rush. Following Arrighi's (1994) theory on capital accumulation, the global land rush delves deeply into the soils and peripheries of the world, in a move from internal capitalization to territorial expansion of globalization (Kröger 2013b). 2 Even within the Nordic states, considered to be focused on high added value production, this phenomenon has become evident in recent years, although the particularities and commonalities in the expansion mechanisms and impacts of these developments are unclear. The under-researched status of the business, the empirical (political/economic) importance of the boom in Finland, the Arctic and global cores, and theoretical opportunities to study the boom as a symptom of wider phenomena linked to control of space, are all reasons for writing an agrarian political economy on the topic. M ost of the discussion about the boom (and bust, in the form of the notorious Talvivaara nickel mine, which has had enormous tailings and production problems, and went bankrupt in November 2014) has taken place in Finnish (and Swedish), although some journalistic reports in English have appeared (see Nimtz-Köster 2012; Helsingin sanomat 2012). There is scarcely any Anglophonic literature on the new Nordic mining, and the specificity of Arctic conditions for resource expansion is largely unstudied in the literature on the new extractivism. How does the global phenomenon of neoextractivism operate in the context of a Nordic welfare state? Also, what explains the rise of neoextractivism in this political-economic context that could be assumed to resist the lure of pursuing capitalist growth via the creation of domestic 'cheap natures'?

To answer these questions, I develop a multi-scalar and interactional analysis of spatial changes. I suggest that drastic changes in the use and outlook of physical space (e.g. establishing open-pit mines) are achieved most easily through a prior and simultaneous changing of capital distribution in both social and symbolic spaces. I analyse these 'horizontal' spatial dynamics across the multiple 'geographical scales' through which they take place, these including: (1) the point of production (new mining projects); (2) regional political economies (Finland, contrasted with the nineteenth-century Gold Rush in California); (3) the position of the larger production zone in the world-system (Arctic as periphery); and (4) the world-economy's historic conjunction (the move to a new 'commodity paradigm', in which the time of 'cheap natures' is over). The second theoretical argument I want to illustrate is that a change in any of these spaces or scales tends to lead to changes in the others, sooner or later.

\section{Capitalism and Spatial Changes}

I argue that symbolic, social and physical space-changes occur as simultaneous, asymmetrical and cascading transformations of ideas, social relations and nature, these being mutually constituted but not equally in all situations: the tendencies and mechanisms of inter- and intra-space changing of power relations are context-specific. Prior research along these lines on global industrial forestry (Kröger 2013a, 2014) has shown how the creation of capitalist class relations in the social space acted as the principal cause leading to changes in the physical space (expansion of tree plantations). This observation is supported by other empirical work on resource booms - for example, by Walker $(\underline{2001}, 168)$, showing how the creation of the Californian natural resource exploitation (with mining in the key role) was based fundamentally on a specific capitalist order in which 'property and class formation established access to resources and motivation for their discovery'. The creation of capitalism and thus the global (or territorially wider-thanbefore) plunder of nature were preceded by cataloguing and reordering of the world in the symbolic sphere (M oore 2014). As M oore $(\underline{2014}, 5)$ has importantly noted, the would-be capitalists of the fifteenth century transgressed both 'intellectual frontiers' and 'medieval territoriality', and these transgressions were paired. To consolidate the claim that ideas also matter is important in countering the resurgence of materialism in theorizing about natural resource politics (M oore 2014): I will offer an analytical framework through which 
both ideas and class relations can be incorporated into an analysis of landscape- and nature-changes, which are not just issues of the economy or of scale, but also of politics in the symbolic and social spaces, and in relations between these. 3 M oore's example above illustrates how the simultaneous changing of symbolic and physical space led to capitalist class relations in the social space; I will seek answers to how a physical space can become rapidly and markedly changed by a resource-extraction boom, through a study of the Finnish mining boom.

\section{The Spatial Causes and Effects of the Resource Boom}

Since the 1990s, Finnish governments have replaced the Nordic welfare-state paradigm with notions of a 'competitive workfare state' based on Schumpeterian economics (Kantola and Kananen 2013): this neoliberal discourse has led to a rapid surge in class inequalities (Patomäki 2007). The mining boom is located within this paradigmatic change in symbolic and social spaces; its study allows an enquiry into the effects of the dismantling of the welfare state, particularly into its causalities in relation to accelerated land-use change and transformations in resource control, with their inherent landscape and environmental impacts. 4

The government has adopted a midwifery role (see Evans $\underline{1995}$ ) to boost rapid expansion, greatly supporting the mining boom by building infrastructure and offering financing. For example, through Tekes, the Finnish Funding Agency for Technology and Innovation, the government is funding a project called 'Green Mining' to the tune of over $€ 100$ million, with the aim of becoming a world leader in environmentally friendly mining technology and practice. Finland is now a laboratory for the future of mining, though with mixed results. At the Talvivaara mine in Kainuu, which commenced operations in 2007, the technology applied ('bioheapleaching') had not been previously tested for nickel, nor in sub-Arctic, Arctic or heavy rainfall conditions, and caused such severe water pollution that it resulted in one of the worst environmental disasters in Finnish history (Flöjt and Flöjt 2012; Knus-Galán 2013). The situation is so dire that the M inister for International Development, Heidi Hautala (17 J anuary 2012, http:// barentsobserver.com), commented that Finland's Northern region 'has turned into a Congo of the North', thereby referencing the tendency of capital to capture mineral wealth at minimal cost and without regard for environmental pollution. The state became a major shareholder in Talvivaara after its second public offering, and the future of the mine after its bankruptcy in November 2014 - closure, sale to foreign capital or continuation via a new injection of government money - is a key political theme in Finland, dividing decision-makers. The negative Talvivaara experience swiftly made many Finns critical about local resource extraction: disappointment is felt in the face of disclosures of revolving doors between politicians/bureaucrats and mining companies, as well as the capture of natural mineral wealth by foreign companies and a small number of individuals, which is allowed by the globally unique capture-based exploration system in the country. The unexpectedly negative physical space-changes have thus led to pressure to recast power relations within social space - and ideologies within symbolic space - in order to influence geographical changes via socio-political processes that shape the state.

Although launching a new, stricter mining law in 2011 and a decree in 2012 (391) on mining activities that further specifies the law - neither of which apply to the companies responsible for the boom, which are still governed by the old, more flexible law - the government has not transformed the capture system governing the contentious mineral and metal property regime. The new law, not a product of the recent governments, has been in the making for a long time, replacing a 1960s law that was found to be obsolete by the State Audit (2007); in fact, the latter was not even followed by authorities facing a new boom. The acutely critical Audit had some impact on drafting a new law, but mostly this was not a response by previous or current governments to curb the boom; quite the contrary, they have retained the essential elements that make Finland a highly attractive mining investment site globally. According to many experts, stakeholders and parliamentarians, including M P Tuppurainen (Social Democrat), the 2011 law-making 
process did not reflect on taxation issues, which was a mistake, as higher mining taxes are urgently needed (see Tuppurainen 2012). It was assumed that corporate social responsibility would be enough to ensure benefit-distribution in the same way as state-ownership of mining companies had done before: politicians assumed that when they provide a favour by offering infrastructure and credits, multinational companies will recompense (see Rytteri 2012). The current legal setting allows for the finder of minerals to claim private ownership over the resource practically for free, making the mineral wealth privatization scheme one of the most liberal and advantageous to companies in the world. $\underline{5}$ Royalties are almost non-existent and taxes low, while government support is robust. 6 It is no wonder that, according to the executives of 742 global mining companies surveyed by the Fraser Institute (2013), Finland was the most preferred investment destination, with the most attractive mining policies from the point of view of exploration managers. Within the current 'competitive state' paradigm, this globally ranked, number one position is understood positively.

The Ernst \& Young (2013) business risk radar for mining and metals reported that the highest risk in the view of global companies in 2008 was skills shortage. Reflecting a major global political change in resource extraction regimes, in 2012 resource nationalism became the top risk for executives (in 2008, this risk was listed as only the eighth most preoccupying factor foreseen for the next 5-year period). Why has this resource nationalism not hit Finland, where conditions allowing for the boom are still present? Politics certainly must be considered. $\underline{7}$

In view of the pro-company social and symbolic space in Finland, the Fraser Institute's study cites the vicepresident of a 'producer company with more than US $\$ 50 \mathrm{M}$ ' who reported that Finland had ' $[\mathrm{n}] \mathrm{o}$ unnecessary regulations and a government that supports mining and clears away obstructions' (Fraser Institute 2013, 57). M ost notable in relation to Finland's number one position is that this is the corporate view, which might not be, and probably is not, a sign of best practices or that the best deal is in place for the investment-receiving area or local inhabitants.

M ost of the other places in top positions in the survey also comprise part of the Arctic or sub-Arctic regions, showing that the northernmost North is regarded as a major destination for future mining expansion. This makes the study of Finland - the most interesting investment destination today for miners - especially important in order to understand the great northward shift in capital's ongoing attempt to effect a socioecological fix to the problem of cheap nature (see Moore 2014). Analysis of the Arctic resource rush broadens the discussion on the post-2007 global land rush as a unique world-systemic change, showing how the phenomenon is greater than previously considered. The facts that global attention is now turning to peripheries of cores, in a period of new resource nationalisms in the South, coupled with the paradigmatic rise in production costs caused by the depletion of the most-easily accessible resources, suggest that the current global conjuncture is not like the prior cycles of $\mathrm{M}-\mathrm{C}$ changes in accumulation focus, but is a new situation.

\section{The Finnish Mining Boom}

The initial boom stage between 2007 and 2010, when metal ore excavation increased from 3.7 to 18.2 million tons (M t), was largely driven by Talvivaara (responsible for $13 \mathrm{Mt}$ in 2010). 8 During that period, however, overall exploration and project-initiation activities exploded as well, and between 2010 and 2014 the distribution of excavation became far less dominated by Talvivaara as other new mines opened. The increase of all mining-related activities, undertaken by numerous companies and in large parts of the country, suggests that this was indeed a boom, and not simply normal growth. Finland has never before seen such fast-paced and large-scale mining expansion. The volume of mining was at its historical peak, with $20.8 \mathrm{Mt}$ of metallic ores and 15.4 Mt of industrial minerals being mined in 2013; the Talvivaara bankruptcy, as well as the facts that the easily appropriated deposits have been claimed now and the 
attitude towards mining has turned markedly more negative in the public eye, while peak prices have also come down, has meant that the boom has subsided and production levels are expected to grow less markedly in the future (while staying at a new level in comparison to pre-boom levels) (TEM 2014). However, this situation can also change quickly, as there are six major mining projects in pipeline, each investment totalling between $€ 450$ million and $€ 3$ billion: the largest is AngloAmerican's Sakatti project, followed by Gold Fields Arctic Platinum's Suhanko project and Yara's Sokli project. These projects are even more controversial than the existing ones. Table $\underline{1}$ and Figure $\underline{1}$ summarize the recent situation.

Table 1. Profit rates, taxation, production capacity and reserves of metal ore mines in Finland, 2010-13

\begin{tabular}{|c|c|c|c|c|c|c|c|c|}
\hline \multirow{2}{*}{$\begin{array}{l}\text { Company name } \\
\text { (mining sites) }\end{array}$} & \multicolumn{3}{|c|}{ Profit rates (\%) } & \multirow{2}{*}{$\begin{array}{l}\text { Average } \\
\text { in all } \\
\text { years }\end{array}$} & \multirow{2}{*}{$\begin{array}{l}\text { Taxation } \\
\text { in } 2013(€)\end{array}$} & \multirow{2}{*}{$\begin{array}{l}\text { Metal } \\
\text { ores } \\
\text { mined in } \\
2012\end{array}$} & \multirow{2}{*}{$\begin{array}{l}\text { Mineral } \\
\text { production } \\
\text { capacity in } \\
2012\end{array}$} & \\
\hline & 2010 & 2011 & 20122013 & & & & & \\
\hline
\end{tabular}

Sources: Author's compilation. Information on profit obtained from taloussanomat.fi; on taxation from vero.fi; and on mineral production capacities and reserve sizes from TEM (2012), PwC (2012) and company websites.

\begin{tabular}{|c|c|c|c|c|c|c|c|c|c|}
\hline $\begin{array}{l}\text { Belvedere } \\
\text { M ining Oy } \\
\text { (Nivala) }\end{array}$ & -32.9 & 4.1 & 4.6 & -27.6 & -13.0 & 0 & $\begin{array}{l}\text { Nickel, } \\
\text { copper }\end{array}$ & $\mathrm{Ni} 2500 \mathrm{t}$ & $\begin{array}{l}1.3 \mathrm{mt} \text { of } \\
\text { ore }\end{array}$ \\
\hline $\begin{array}{l}\text { Outokumpu } \\
\text { Chrome Oy } \\
\text { (Kemi) }\end{array}$ & 31.6 & 18.2 & 6.9 & 16.9 & 18.4 & 18 & Chrome & $\mathrm{Cr} 1.3 \mathrm{mt}$ & $\begin{array}{l}140 \mathrm{mt} \text { of } \\
\text { ore }\end{array}$ \\
\hline $\begin{array}{l}\text { Agnico Eagle } \\
\text { Finland Oy } \\
\text { (Kittilä) }\end{array}$ & 28.5 & 35 & 52.2 & 40.4 & 39.0 & $11,629,943$ & Gold & Au 160,000 oz & $\begin{array}{l}5.2 \\
\text { million } o z\end{array}$ \\
\hline $\begin{array}{l}\text { Dragon M ining } \\
\text { Oy (Orivesi and } \\
\text { Huittinen) }\end{array}$ & 30.1 & -13.5 & -39.3 & -72.2 & -23.7 & 0 & Gold & Au 25,720 oz & $\begin{array}{l}488,500 \\
0 z\end{array}$ \\
\hline $\begin{array}{l}\text { Pyhäsalmi M ine } \\
\text { Oy (Pyhäsalmi) }\end{array}$ & 56.5 & 57 & 51.8 & 43.7 & 52.3 & $1,777,846$ & $\begin{array}{l}\text { Copper, } \\
\text { zinc, } \\
\text { silver, gold }\end{array}$ & $\begin{array}{l}\text { Cu } 14,000 \text { t; Zn } \\
32,300 t\end{array}$ & $\begin{array}{l}17.1 \mathrm{mt} \\
\text { of ore }\end{array}$ \\
\hline $\begin{array}{l}\text { Talvivaaran } \\
\text { Kaivososakeyhtiö } \\
\text { Oyj (Sotkamo) }\end{array}$ & -52.7 & -38.9 & 0.1 & -110.9 & -50.6 & 0 & $\begin{array}{l}\text { Nickel, } \\
\text { copper, } \\
\text { zinc, } \\
\text { cobalt }\end{array}$ & $\begin{array}{l}\text { Ni 50,000 t; Zn } \\
100,000 \text { t; Cu } \\
\text { 15,000 t; Co } \\
1,800 \text { t }\end{array}$ & $\begin{array}{l}4.5 \mathrm{mt} \text { of } \\
\text { nickel } \\
\text { and } 10.3 \\
\text { mt of zinc }\end{array}$ \\
\hline $\begin{array}{l}\text { Endomines Oy } \\
\text { (Ilomantsi) }\end{array}$ & -894.1 & 7.2 & 27.5 & -45.2 & -226.2 & 0 & Gold & $\begin{array}{l}\mathrm{Au} \\
25,700-28,900 \\
\text { oz }\end{array}$ & 38,141 oz \\
\hline $\begin{array}{l}\text { Nordic Mines Oy } \\
\text { (Raahe) }\end{array}$ & -16 & - & -53.1 & -193.5 & -87.5 & 300 & Gold & Au $118,0000 z$ & $\begin{array}{l}12.9 \mathrm{mt} \\
\text { of ore }\end{array}$ \\
\hline
\end{tabular}


Table 1. Profit rates, taxation, production capacity and reserves of metal ore mines in Finland, 2010-13

\begin{tabular}{|c|c|c|c|c|c|c|c|c|c|}
\hline \multirow{2}{*}{$\begin{array}{l}\text { Company name } \\
\text { (mining sites) }\end{array}$} & \multicolumn{4}{|c|}{ Profit rates (\%) } & \multirow{2}{*}{$\begin{array}{l}\text { Average } \\
\text { in all } \\
\text { years }\end{array}$} & \multirow{2}{*}{$\begin{array}{l}\text { Taxation } \\
\text { in } 2013(€)\end{array}$} & \multirow{2}{*}{$\begin{array}{l}\text { Metal } \\
\text { ores } \\
\text { mined in } \\
2012\end{array}$} & \multirow{2}{*}{$\begin{array}{l}\text { Mineral } \\
\text { production } \\
\text { capacity in } \\
2012\end{array}$} & \multirow{2}{*}{$\begin{array}{l}\text { Reported } \\
\text { reserve } \\
\text { size }\end{array}$} \\
\hline & 2010 & 2011 & 2012 & 2013 & & & & & \\
\hline $\begin{array}{l}\text { Kylylahti Copper } \\
\text { Oy (Polvijärvi) }\end{array}$ & -6078 & -3235.5 & 5.8 & 24.9 & -2320.7 & 0 & $\begin{array}{l}\text { Copper, } \\
\text { cobalt, } \\
\text { nickel, zinc }\end{array}$ & $\begin{array}{l}\mathrm{Cu} 8,000 \mathrm{t} ; \mathrm{Au} \\
8,400 \mathrm{oz} ; \mathrm{Zn} \\
1,600 \mathrm{t}\end{array}$ & $\begin{array}{l}17.8 \mathrm{mt} \\
\text { of ore }\end{array}$ \\
\hline $\begin{array}{l}\text { FQM Kevitsa } \\
\text { M ining Oy } \\
\text { (Sodankylä) }\end{array}$ & - & - & - & - & - & 0 & $\begin{array}{l}\text { Nickel, } \\
\text { copper, } \\
\text { platinum, } \\
\text { palladium, } \\
\text { gold }\end{array}$ & $\begin{array}{l}\text { Ni } 10,000 \text { t; } \mathrm{Cu} \\
20,000 \mathrm{t}\end{array}$ & $\begin{array}{l}240 \mathrm{mt} \text { of } \\
\text { ore }\end{array}$ \\
\hline
\end{tabular}

Averages $\quad-769.7-395.8 \quad 6.3 \quad-35.9 \quad-290.2 \quad 1,340,811$ 


\section{Active Metal Ore Mines and Current Projects}

April 2014

\section{Precious Metals}

1. Iso-Kuotko gold - Agnico-Eagle Ltd

2. Hanhimaa gold - Dragon Mining Ltd \& Agnico-Eagle Ltd JV

3. Kittilä gold - A gnico-Eagle Ltd

4. Kettukuusikko gold - Taranis Resources Inc

5. Naakenavaara gold - Taranis Resources Inc.

6. Pahtavaara gold - Lappland Goldminers Ab

7. Rompas gold, uranium - Mawson Resources Ltd

8. Suhanko-Konttijārvi PGE - Gold Fields Arctic Platinum Oy

9. Kuusamo gold - Dragon Mining Ltd

10. Laiva gold - Nordic Mines Ab

11. Antikanperä, gold - Belvedere Resources Finland Oy

12. Hirsikangas gold - Belvedere Resources Finland Oy

13. Angesneva gold - Belvedere Resources Finland Oy

14. Kopsa gold - Belvedere Mining Oy

15. Piilola gold - Mineral Exploration Network (Finland) Ltd

16. Taivaljärvi silver - Sotkamo Silver $A B$

17. Pampalo gold - Endomines Oy

18. Hattu Belt gold - Endomines Oy

19. Seinäjoki gold, antimony - Nortec Minerals Copr.

20. Osikonmäki gold - Belvedere Resources Finland Oy

21. Orivesi gold - Dragon Mining Ltd

22. Jokisivu gold - Dragon Mining Ltd

23. Kaapelinkulma gold - Dragon Mining Ltd

\section{Base Metals}

1. Riikonkoski copper, gold - Taranis Resources Inc.

2. Kevitsa nickel, copper, PGE - First Quantum Minerals Ltd

3. Sakatti nickel, copper, PGE - AA Sakatti Mining Oy

4. Läntinen Koillismaa (LK) nickel, PGE - Finore Mining Inc.

5. Kuhmo nickel - Altona Mining Ltd

6. Kuhmo nickel - Anglo American Exploration B.V.

7. Talvivaara nickel, zinc, copper - Talvivaara Mining Co.

8. Hitura nickel - Belvedere Mining Oy

9. Pyhäsalmi zinc, copper, pyrite - First Quantum Minerals Ltd

10. Kylylahti copper, gold, zinc, nickel, cobalt - Altona Mining Ltd

11. Outokumpu copper - FinnAust Mining Plc

12. Hammaslahti copper - FinnAust Mining Plc

13. Valkeisenranta, Särkiniemi nickel, copper - Altona Mining Ltd

\section{Diamond}

1. Kuhmo - Karelian Diamond Resources Plc

\section{Other Commodities}

1. Kolari iron, gold, copper - Northland Resources $\mathrm{Ab}$

2. Kemi chromium - Outokumpu Chrome Oy

3. Mustavaara vanadium - Mustavaaran Kaivos Oy

4. Otanmäki vanadium, iron, titanium - Vuorokas $\mathrm{Oy}$

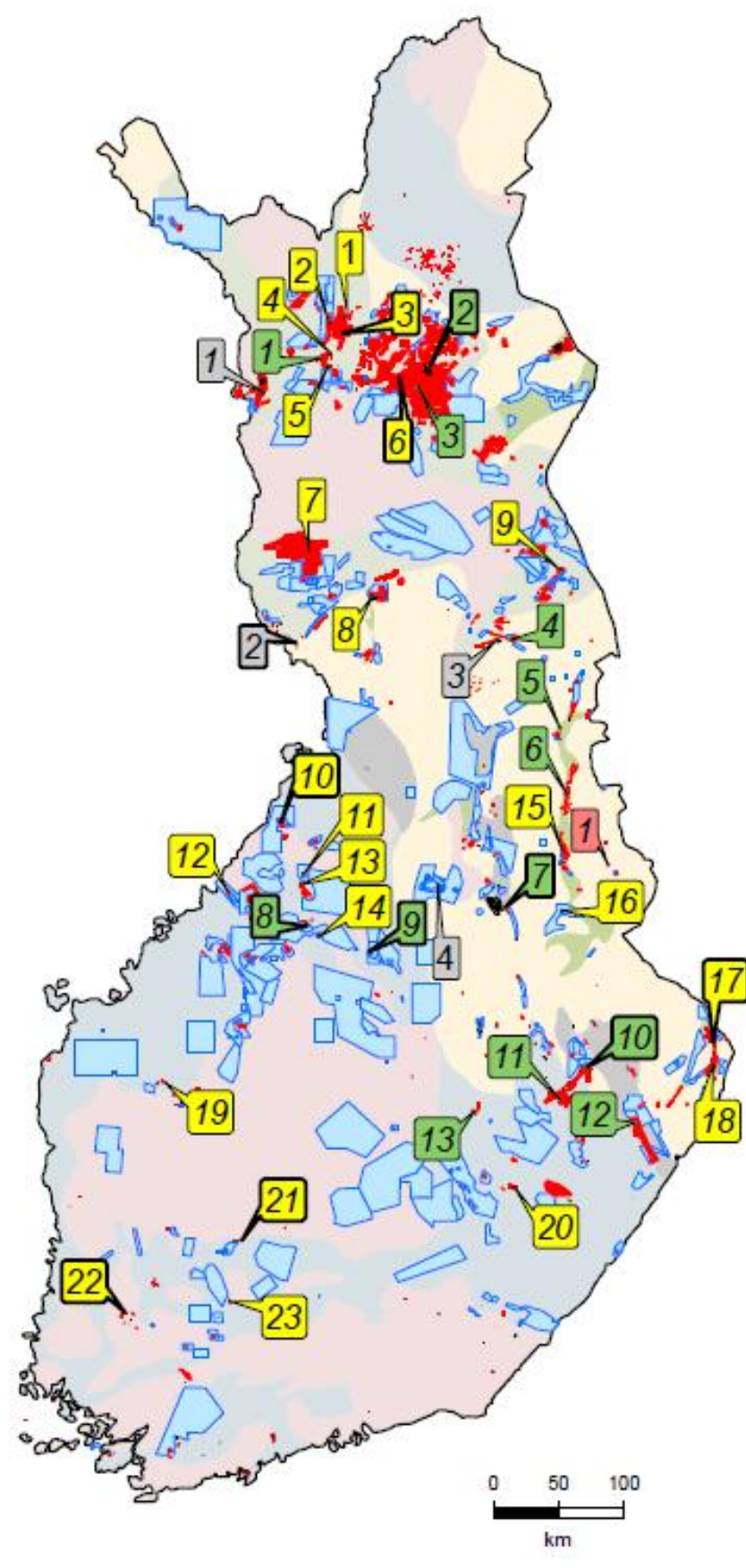

Land Tenure 7 April 2014

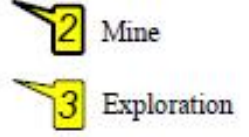

Mining Concession

Claim/Exploration permit

Reservation 
Figure 1. Finnish metal ore mines and projects in April 2014

Source: GTK ( $\underline{\text { n.d. }}$ ); reprinted with the permission of GTK.

The nominally most valuable existing metal deposits in Finland are nickel (with reserves to the value of almost $€ 80$ billion) and chromite (almost $€ 60$ billion). The total values of all the other metal deposits are estimated at fewer than $€ 20$ billion (TEM 2012). Of the industrial minerals, the phosphate deposits in Sokli alone have been estimated to be worth at least $€ 13$ billion, possibly tens of billions. 9 Over 15 per cent $\left(51,000 \mathrm{~km}^{2}\right)$ of the overall land surface of Finland $\left(338,434 \mathrm{~km}^{2}\right)$ and almost a third of Lapland had become reserved in one or another way for the mining industry by early 2013. This total included reservation, exploration and mining permit areas, with the bulk being reservations, a status that grants a privilege with regard to the submission of an ore-prospecting application (Tukes 2013). If ore is found, ownership of the ore is given to the finder. Finland has no mining royalties or tax and does not retain ore or mineral ownership while leasing or renting the excavation rights, as some countries do. Under the new $\mathrm{M}$ ining Act (621/2011), the landowner will get $€ 20$ - 50 per hectare while exploration is being carried out, and $€ 50$ per hectare plus 0.15 per cent of the worth of yearly excavated metals when there are mining operations in place. The corporate tax was lowered from 24.5 per cent to 20 per cent in 2013, which is much lower than the average in the European Union. Not many of the new companies have paid these taxes, as they have not recorded profits: such has been the case of the biggest mine, Talvivaara, for example, which made huge losses (which are fully deductible for 10 years) before its bankruptcy. 10 Finland is one of the only countries in the world where a mine can free itself completely from royalties and payments made to landowners: this is possible if it manages to buy the land where the mine is located (in many countries, mines still have to pay royalties on, for example, earnings or extracted volume, even though they own or control land).

\section{The Theory of Spatial Causalities}

Figure $\underline{2}$ outlines the theory of spatial analysis that I use in this paper, illustrating the social, symbolic and physical spaces as internally differing topologies of power relations as well as interrelated and interchangeable spaces: $\underline{11}$

- The social space power relations and topology are defined by the distribution of economic (money), social and cultural capital, and the social acts that change the distribution of these between actors.

- Physical space includes the body, land, objects and other forms of nature, as well as visible artefacts such as text and pictures in existing virtual worlds such as the internet. Besides the distribution of access to and control over these forms of physical capital, the power relations of the physical space are defined through physical acts.

- The symbolic space power relations are likewise defined by both differences in symbolic capital distribution and symbolic acts. Symbolic capital can legitimize capital-differences and ensures complicity in spite of inequalities. Symbolic space deals with legitimization battles.

- 'Symbolic acts of merit', a concept of mine not presented by Bourdieu, who did not consider morality or ethics as significant strategies of distinction, differ from 'symbolic capital' in that their power does not come from capital in other spaces that is misrecognized, but are based on real competence, skills or acts of truth where an agent displays morality, courage, strong will or humility for the sake of the value of such symbolic acts by itself, and not as a means to gain physical or social power (to which end the accrued symbolic power can nevertheless be used). Such symbolic acts of merit can be used to change positionings in the symbolic space in spite of one's lower position in the other spaces. Symbolic acts of merit work as the mechanism of internal changing of symbolic 
space-positioning/relations. Honour, trustworthiness, respect and charisma can derive their power both from symbolic capital and 'symbolic acts of merit'.

An actor can gain power in all three spaces by either internal, space-specific acts or by using inter-space mechanisms. A mechanism that can be used to link physical and symbolic space is the creation of objectified symbolic power. This tool of inter-space change links physical space-changes to their symbolic dimensions. The social and symbolic spaces can be linked by creating institutionalized symbolic power. Both of these tools can be used either way, from physical to symbolic, social to symbolic or vice versa - and can be linked also via the other space to the third space.

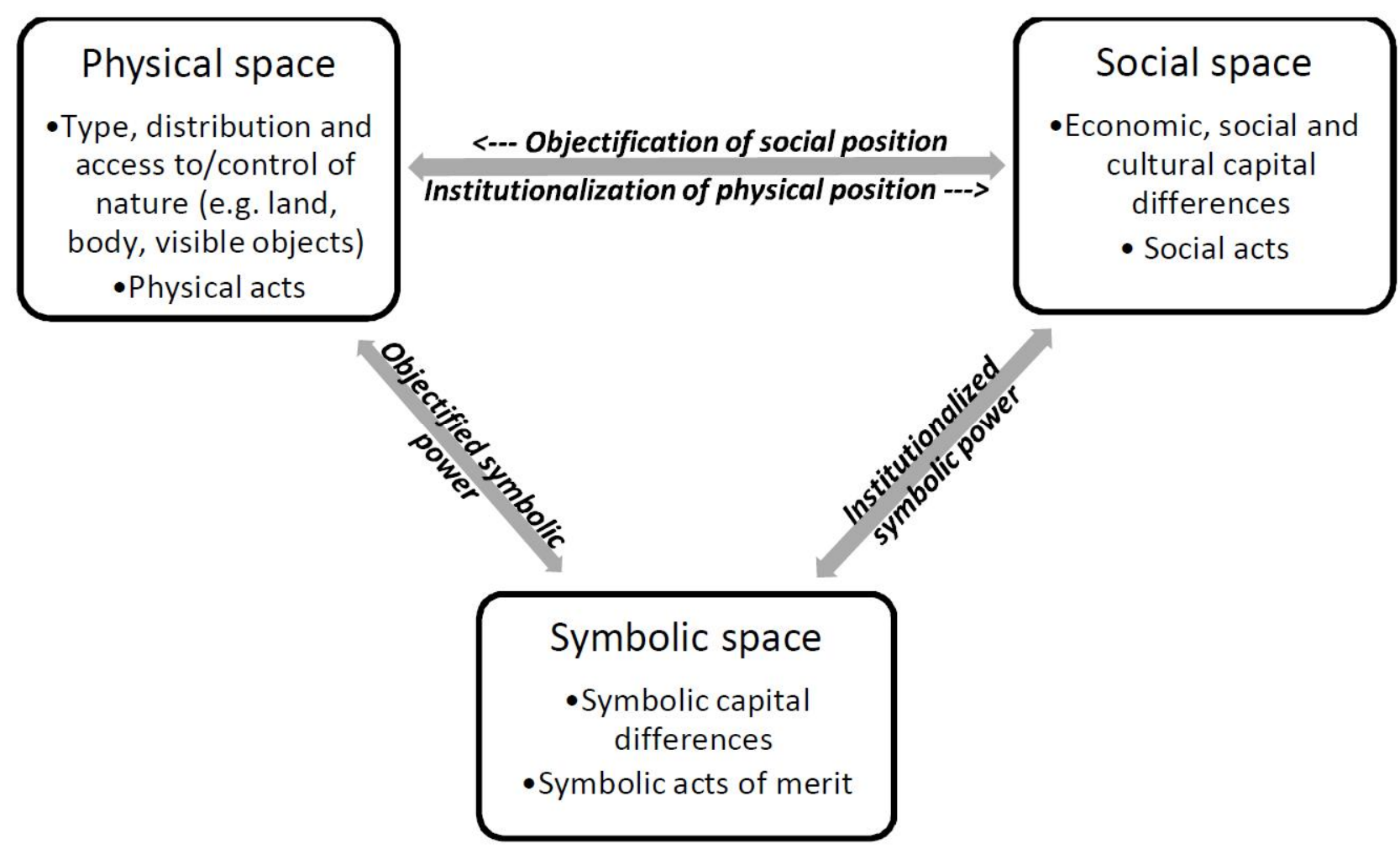

Figure 2. A theory of physical, social and symbolic space as interrelated and internally distinguished spaces for changing the power relations, differentiation and positioning of social actors

The position of a social actor in the social space can be put into a homology with physical space by what I call objectification of social position (see Figure 2, top arrow); for example, by using capital to transform one's body via plastic surgery, moving to a new neighbourhood, creating a website, or buying a mineral deposit and opening up a mine. Institutionalization of physical position can be used to link one's physical space-position to the social space; for example, by forming a company or association named after a place where one has customarily lived, allowing the thus-institutionalized form of physical place to be legalized and made changeable (by sale).

I argue that when both social and symbolic spaces are simultaneously changed, the conquest of physical space can be done more rapidly and thoroughly: in this paper, I show how resource booms can be explained through such an increase in multi-spatial power, favouring the exploiters.

\section{The Causes of the Boom Through the Eyes of Key Policy-Makers}

To analyse the causes of the boom in a balanced and comprehensive way, I collected the viewpoints of all key actors, described and discussed in this section. Research was conducted via a thorough analysis of 
existing policy documents, participant observation of mining projects and political meetings related to them, and confidential interviews with key policy-makers; these semi-structured interviews ranged in length from between 1.5 to 5 hours. M ost of the interviews took place in 2013, in Lapland. The 26 interviewees included representatives of the most important state regulatory authorities (mining, environmental impact, the economy and employment officials), of business (chambers of commerce, directors of mining firms) and civil-society actors (reindeer herders, socio-environmental activists, researchers). People from very different backgrounds were included, so as to maximize the number of different explanations given, and enable examination of necessary and sufficient causal conditions behind the boom. A systematic study of the various perspectives via the method of qualitative comparative analysis (Ragin and Strand 2008) was used to pursue a balanced account of events and the causal order, and helped to assess the interview data systematically.

In the in-depth key-actor interviews, some explanations surfaced more potently than others. I summarize the findings below, including informants' excerpts in abbreviated form. I then note (in parentheses) the specific interlinked character or causal link of spatial change that the research material in question suggests is/are in place.

\section{Spatial Analysis of Boom Causalities: Key Explanations}

The strongest causal explanation by the group of key actors interviewed was that:

- Change to a stricter mining law (2011) was foreseen by investors and drove the boom, as investors strove to start projects before this date, so as to be ruled under the old, more lax mining law (objectification of social position and creation of objectified symbolic power for new mines by the existing [more lax] rules $\rightarrow$ physical space-change to avoid being ruled under less favourable interand intra-space rules and mechanisms in the future).

After this causal condition, mentioned by all but one of the informants, and by one of them as the key explanation, came two explanations that received the same amount of support:

- Structural economic transformation has cut jobs in rural areas; employment is seen as much more important than nature conservation by locals (social space-change $\rightarrow$ symbolic space-change via creation of institutionalized symbolic power to mining companies as job-creators $\rightarrow$ objectified symbolic power to mines).

- A rights system based on capture is trusted by the industry, giving security of tenure (the mechanism of institutionalizing physical-space claims/ positions in Finland is far more favourable to global mining capital than in other regions $\rightarrow$ physical change).

The first explanation suggests that the (anticipated) changing of inter-space rules and mechanisms is even more important than intra-space changes in explaining physical transformation. The second explanation shows how interspatial causality can run from social space-change (structural economic transformation via neo-liberal policies) to physical space via the symbolic space. The third explanation illustrates how regional spaces are globally scaled. These explanations also suggest that the creation of new capitalist class relations (in social space), moving capital from state ownership to private and global corporate ownership, has led to what Wright (2005) calls changes in the power to decide how capital and labour are employed, favouring mining jobs over other jobs, and thus driving the objectification of the new capitalist power by the opening of new mines. Symbolic space-change in the form of promoting pro-mining views as a solution to the problems of Finnish economy has deepened this causality.

The explanation gaining fourth most support was as follows: 
- The creation of a mining elite - 'the old men of Outokumpu': a narrow group of mining experts consulting with new investors for private gain, with privileged information (hierarchization of social space, accumulation of social capital $\rightarrow$ objectification of social position by claiming deposits for the inner circle).

The small number of mining experts was a consequence of the prognosis of the demise of Finnish mining operations in the 1990s, when the directors of Outokumpu, for example - the largest national mining company at that time - announced that mining would no longer be a key industry in Finland, as all major deposits had been extracted or were no longer profitable. 12 This led to a radical cut in the education of new professionals for the mining sector. According to two interviewed industry representatives, when the mining boom began, approximately 30 key persons ran the business and the bureaucratic systems and knew how they operated. It is intriguing that a boom was launched at a moment when the pool of experts who could reap the highest benefits from it as directors, shareholders and consultants - as mediators between foreign prospecting/mining companies and national regulatory bodies and politicians - was shallowest. This suggests that drastic and rapid changes in class relations can boost extraction booms, the forming of class relations being the central component in constructing positions and relations in social space.

M ost of these key persons were linked to Outokumpu, and in most cases its previous mining directors. In the 1990s, they made the decision to sell the company's mines, when mineral prices were at their lowest, just prior to their new global boom. Large deposits were privatized, typically sold to foreign companies. The Outokumpu directors became consultants, owners, board members and directors in the new companies, and still run operations. 13 In this way, the physical space claimed by the state-company elite was institutionalized into a (higher) social-space position, leading to a privatization of the deposits. The bestknown example is Pekka Perä, to whom Outokumpu (where he previously worked, and where his former colleagues were making the decisions) sold the Talvivaara deposits for $€ 1$. He then managed to raise $€ 1.9$ billion using, for example, the London and Helsinki stock exchanges, in order to open the nickel mine of which he was the principal owner (but not any more).14 Perä's ownership of the company was valued at over $€ 350$ million at one point; he managed to save from that sum, through sales of stock, at least over $€ 20$ million worth of taxable income (which is considerable wealth creation, considering that he bought the mine for $€ 1$ ), becoming one of the wealthiest persons in Finland. 15 In the public discussion around the topic, Perä has been called a neo-liberal oligarch, who leaves the payment of costs to taxpayers - the cost of cleaning up the environmental damage of the bankrupt mine is estimated at between $€ 450$ million and $€ 1$ billion.16 It is the Finnish state that has to pay for this damage. It is claimed that CEO Perä and other key executives knew of the problems that the mine would probably cause, but did not reveal them, for which reason on 22 September 2014 public prosecutors charged the executives with criminal negligence in the design and research phase of the nickel mine, as well as negligence in the environmental and water management permit application; the operators in charge of the construction and commission of the gypsum pond that was the source of the leaks and the mine's waste treatment and disposal facilities were also charged.17 After the November 2014 bankruptcy, chairman Rothovius, from the Finnish Stock Investors' Association, argued that the company had systematically and even criminally misled shareholders with overtly optimistic promises in all of its public offerings; for him, the bankruptcy came as no surprise, but he was surprised that the authorities had not intervened earlier to stop the misleading communication.18 On 17 June 2015, Economic Affairs M inister Olli Rehn said that the government will sink at least $€ 200$ million into Talvivaara 'to get the mining operation back on its feet during the summer' - but only to 'sell' (meaning giving for free, at a loss) the operation to the British investment firm Audley Capital Advisors, which has not been able or willing to secure financial resources of its own to resuscitate the mine and will eventually 'close the mine at the state's expense'.19 M eanwhile, the new Finnish government of 
2015 is more pro-mining than the preceding ones, and is cutting heavily in almost all other areas of the budget.

Another social driver of the boom, besides the positional move from executive to major capitalist that Perä exemplifies, has been the fluidization of class lines and allegiances among the key bureaucratic socialposition holders that favour mining capital at the cost of the public interest. For example, Juha Koskela worked as a referendary regulator (chief environmental inspector at Northern Finland's Regional State Administrative Agency) when Nordic M ines received a permit for its Laiva gold mine in Raahe in 2009; after providing the permits, he started working as the mine's environmental and security chief, receiving stock options in 2011 for his key role (Kaleva 2012). The director of the same mine, Krister Söderholm, is a former chief mining inspector at the M inistry of Trade and Industry (which issues mining licenses). During their offduty periods, bureaucrats Erkki Kantola from northern Finland's environmental licensing agency and Juhani Itkonen from Lapland's environmental centre have both worked as environmental directors at the Kittilä gold mine (Suurikuusikko, owned by the Canadian Agnico Eagle). Heikki Kovalainen, environmental geologist at the Kainuu Environmental Centre, moved to Talvivaara to work as the company's environmental chief. There are also other cases where bureaucrats with key regulatory power to issue permits to mines have worked for some period of time, before or after playing these roles, in executive positions in mining companies. After media criticism of this state of affairs, the off-duty periods during which a bureaucrat can utilize the revolving doors were limited to one visit per company; the retention of the right was defended on the basis that it is necessary that bureaucrats be continually updated about current practices in the mining sector.

\section{Spatial Analysis of Boom Causalities: Multiple and Converging Causes}

The following explanations, gaining intermediate support among the key actors, enable further analysis of the spatial dynamics in resource booms (a brief analysis of the spatial cause promoting the boom is in parentheses following the quoted speech). The high number of explanations suggests that booms are complex and occur due to multiple and converging causes:

- M ineral wealth had not been discussed politically; there has been no long-term planning (conservative symbolic space with lack of knowledge, ideas and contentious discourses $\rightarrow$ weak power for heterodox political symbolizations to counter the power of capital).

- There is an unclear land tenure situation with regard to traditional populations: ILO 169 has not been ratified to give rights to indigenous and traditional reindeer-herding people and livelihoods in Lapland (maintenance of hierarchical social space $\rightarrow$ the symbolic capital/violence of those in top social positions has trumped the symbolic value of indigenous people and traditional cultures/livelihoods; 'indigenous symbolic power' has been weakly institutionalized, and thus also weakly objectified).

- The logistics are good, with infrastructure that supports investment20 (existence of suitable physical space for a cross-scale expansion of global mining capital to Finland).

- A clear (pro-mining) legal and operational framework (non-contentious symbolic-space and socialspace rules of capital accumulation and tenure favour the deepening of mining capitalism).

- The political hegemony of the pro-mining caucus led by the Centre party in the potential mining areas; a lack of debate and the presence of a patriarchal, male-dominated, criticism-averting political culture in these settings (dominance of orthodoxy in symbolic space $\rightarrow$ symbolic violence concealing appropriation of nature in the corresponding physical spaces). 
- The authorities and industry have disseminated misinformation, such as low estimates of the impact on locals and/or improper persuasion techniques in land deals, using a harsh and aggressive negotiating style (increase in symbolic capital $\rightarrow$ unperceived transformation of symbolic space into a situation in which some social actors in top positions do not obey the established social rules of communication, but misuse the old assumptions of honour and trustworthiness).

\section{Geographical-Scale Expansion}

There were also a number of boom explanations that were less frequently proffered than those presented above, due to the specific knowledge of mining markets that was required. These explanations were more related to geographical scales and the global position of Finland and the new mining projects in those scales, and included the following:

- Technology has developed.

- The Finnish geological landscape is similar to parts of Canada and Australia where metals have been found; there is, therefore, a belief on the part of foreigners who have expertise in recognizing the similarities that ores are also likely to be found here.

- To support Finnish mining technology development, clustering and exports. 21

These points illustrate how booms depend on the past trajectories and spatial immersions of those working to expand production, particularly on geographical scales. It is likely that experience in operating in one type of physical space (e.g. the geologies of Canada and Australia) promotes expansion of the production systems operating there to other similar territories, provided that the receiving countries have social and symbolic spaces that allow this potential foreignization of place. It is evident that the Finnish national mining technology sector is bound, therefore, also to play a greater role abroad, particularly in the Arctic, based on the current territorial-change trajectory that is creating a global thrust for the industry as a result of the national boom.

The mention of national 'technology development' above illustrates that the Finnish boom is not just a 'spatial fix' (in Harvey's $\underline{2003}$ terminology), but also represents M -C-M + capitalization (following Arrighi 1994); both of these can thus exist simultaneously. Drawing on M oore (2014), this capitalization of value is possible exactly because the development of mining technology relies on an appropriation of unpaid labour (nature) by a mining boom. Such capitalization, however, typically yields benefits almost solely in the technological cores, while resource peripheries do not experience the development of local capital goods barely exporting raw materials - in a lopsided inter-industrial trade (Bunker and Ciccantell 2005). The existence of strong mining-technology capitalization in Finland, with a globally notable mining technology sector already in existence, is one of the key drivers of the boom, according to many of those interviewed. 22

\section{Contentious Causalities}

Finally, there was a group of explanations that received both strong support and strong opposition. These causal conditions were clearly a matter of important political and interest-based struggle, as they were the subject of argumentation, either placing them in a central place or framing them as unimportant. All the previously mentioned causal explanations resulted in consensus or, at least, an absence of strong opposition or negative opinion, but those discussed below were bones of contention:

- The new regulatory structure created in 2010 (ELY and RSAA, Tukes) suffers from conflict-ofinterest problems (revolving doors), lacks resources and is not working effectively; this has boosted mine expansion. 23 (The physical-social space-linking rules, defining how the mechanisms for 
institutionalizing physical position and objectifying social position function, no longer ensure the rule of law, nor bar those with privileged social power from objectifying this power by claiming physical space and then institutionalizing the claim under private ownership.)

Three saw this condition as a cause, with two denying the claim. Interestingly, the two who rejected the significant importance of the regulatory reshuffle/ capture or the revolving doors came from opposing camps (one critical and the other supportive of mines). The boom was in place before 2010, so in this sense the gainsayers have a point: it seems neither a sufficient nor a necessary cause but, rather, a qualitative condition explaining a greater acceleration and a more reckless style of boom and not the boom itself. In this sense, this social space- and inter-space mechanism-twisting is a consequence of the new intra-space hierarchies discussed above. Another contentious explanation for the boom was that:

- The state has conducted extensive geological surveys and has sold or given away the information and deposits to boost mines. 24

Without the state's geological surveys, the current mining boom would not exist, as it would not have had the information on which to base the mining operations: this causal condition can thus be considered necessary, but not sufficient. The point illustrates how physical space is created, and that such creation of physical territory - for example, by means of mineral mapping - is necessary for land rushes to occur. The same was found by Walker (2001), noting how US geologists were aware of the California gold prior to the war with Mexico in the mid-nineteenth century. This creation of new mineral-wealthy space led to a geographical-scale change to extend the US socio-symbolic-physical space to California through warfare. The existing extensive mapping and cataloguing of mineral wealth also supports M oore's (2014) claim that ideas, counting and knowledge precede capitalist expansion.

- Low mining taxation.

A few bureaucrats named this as a cause, while the industry denied its contribution to the boom by emphasizing that Finland's policies still mean that companies incur steep costs in terms of a global comparison, although royalties are low (this argumentation being that of lobby groups). This is also a cause related to a hierarchized social space, which surfaces as the crucial, although not a sufficient, spatialchange dimension explaining the Finnish mining boom. I will next deepen the analysis of capitalism's key role in resource rushes. I will start by analysing in detail the last of the contentious explanations, which posited that the rise in global mineral prices would mostly or alone explain the boom.

\section{The Role of Profitability and Commodity Prices}

Global commodity price-rise was one of the most interesting explanations that cropped up, as two informants named this as the principal explanation for the boom (both were pro-mining), while two others, aligning more with the critical side, rejected this as the primary causal force. Those denying the primacy of the price-rise condition named this 'a politically value-free explanation' or as a cause 'that they [pro-mining people] give'. From an academic, comparative perspective, global prices alone do not constitute market calculation by investors: more important are profit margins, which might increase in a situation where global prices decrease but political/regulatory frameworks become more flexible. In this sense, the pricerise explanation can be considered too simplistic, particularly if offered as the sole cause. It may be a sufficient, but not a necessary, condition. Its importance depends on whether the key capitalists can raise profits only, or mostly, as a result of price rises, given the constraints faced by capital accumulators in the spaces and scales in which they operate.

Finland's metal mines can hardly be said to be or have been profitable. Table 1 illustrates that the average profitability of metal mines on which data was available between 2010 and 2013 was -290 per cent. The 
only year when mines were on average profitable was 2012 (6.3\% profit rate). In 2013, mining made a loss of $€ 1.5$ billion, which was almost the same as the sector's turnover. 25 Agnico Eagle's Kittilä mine is the only new or open-pit mine that has been consistently profitable. It seems to be the case that mines are divided into two very different groups: three mining companies that are able to produce 'cheap natures' (their profitability being on average $36.6 \%$ ), these showing far higher rates than is typical in other sectors in Finland, and then the majority, the bulk, the rest of the companies, which are not able to produce cheap natures (at least reportedly), or manage this only in some years (their average profitability between 2010 and 2013 being $-469.5 \%$ ).

The type of metal mined was not significant in explaining the differences in profitability, as the same metalfocusing companies recorded dramatically different levels of profitability. Thus, operating costs seem to be more important than the global commodity prices in explaining profitability: even as gold and copper prices peaked, in 2010-13, there were several companies extracting these minerals with heavily negative profitability. The production costs in mining are rising almost everywhere around the world, and this is also visible in Finland. However, as production costs have also been higher before in Finland, the relatively higher cost increases in the rest of the world have meant that the well-operating mines (e.g. the profitable ones in Table 1) have been able to record a level of profitability that is far above average business profit rates in Finland. Thus, the global rise in production costs can be said to have boosted the mining boom in Finland: but this has also meant that those unable to curb costs by making their operations function effectively have made record losses, in spite of high commodity prices.

It is hard to base mining boom causalities on profitability or commodity prices: profitability is essential in capitalist value creation, but costs, particularly the inability to pay full costs, matters more than commodity prices. The high prices of zinc and nickel before the boom, and the global metals boom in general, surely attracted mining capitalists to Finland in the late 2000s. But more than that, they were attracted by the neo-liberal regulatory framework that enabled the boom, and the role of the state's midwifery and the 'middlemen' of the new mining elite in driving the boom: what these two basically did was to allow for mining costs to be externalized.

\section{A Spur of the Capitalocene in the Arctic}

The Finnish mining boom has been a visible emblem of how, in terms of M oore's (2014) study of the past five centuries as the Capitalocene, capitalist value creation relies essentially on accumulation by appropriation of unpaid work of human and extra-human nature. By appropriation of unpaid work, M oore (2014) refers to the fact that capitalism was based, from its beginning in about 1450, on appropriation of human work through slavery and extraction of value from the unpaid domestic work of women, and appropriation of the rest of nature through 'environmental services' and plunder. M oreover, M oore argues that exploitation (i.e. increase in paid work) has increased much less than appropriation (unpaid work), with 'environmental services' accounting, for example, for between 70 and 250 per cent of the world's GDP. This notion is also a very poignant indicator applicable to the Finnish mining boom, where in comparative terms the mines employ only a few people, about 2,300 currently (job creation being the most-cited positive argument) but, crucially, are based on large-scale appropriation of both extra-human nature and of the work of those being damaged by the mine but not receiving compensation (polluted households, fishermen having had to abandon their lakes, the tourism industry losing customers, forest owners losing felling sales, and reindeer herders and animals stripped of access to land).

In a report commissioned by the Finnish Association for Nature Conservation on Talvivaara's hidden risks, a group of expert environmentalists argued that the company's turnover has been largely based on environmental irresponsibility and the externalization of costs to nature, and the neglect of critical safety measures.26 The emergence of such mining projects in countries with Arctic territories and welfare state 
histories suggests that capitalism - as 'a frontier civilization' in M oore's (2014) terms - is now also penetrating truly and more deeply than before into the Global North of the capitalist 'cores', rendering their internal peripheries into peripheries of global capitalism, which needs new frontiers in order to continue as a system.

This Arctic Frontier of appropriation is not just out there, but is actively constituted and shaped by agency. As a capitalist value-creating system, a commodity frontier is constituted by the interplay of capitalist and anti-capitalist actions in the symbolic, social and physical space. The capitalist acts aim to ease the attainment of Four Cheaps (cheap labour, food, energy and raw materials), while anti-capitalist actions seek to resist this this process. It is these dynamics of frontier-making in the Arctic, visible through the historical conditions of 'cheap nature' in mining and Finnish society, on which I have focused so far, and the analysis of which I will next deepen, by focusing first on the contentious agency of the Sámi and then the corporate-governmental strategizing.

\section{Political Dynamics and Landscape Changes}

Drastic landscape changes have triggered political dynamics that are critical of mining across the globe (Bebbington 2012). Global resistance has increased in order to avoid, in advance, environmental side effects that often follow the economic 'resource curse' that an overdependence on resource frontier expansion creates for a country. For example, northern Sweden is experiencing unforeseen mining protests from indigenous Sámi populations in the iron-mining green-field belt in Jokkmokkve, with protesters hospitalized in clashes with police securing wilderness access for a foreign mining company. This level of contentious protest has not yet been seen in Finland, though leaders of the indigenous Sámi community have voiced their outright objection to any mining projects in the lands in which they mostly reside (the two northernmost municipalities in Finland, Inari and Enontekiö). 27 The Sámi are living through a historic upsurge in resistance to their centuries-long colonization: also, those who have become critical of mines within the general Finnish population have become more systematic, networked and better organized in their resistance, filing complaints and protesting. These acts of resistance, particularly the knowledge practices created and suggested by them as a way for the typically passive citizens to steer their action towards contentious agency (Kröger 2013a), have been taken much more seriously after the problems have become undeniable.

However, corporate agency and pro-mining state remediation of resource politics have been far more central in steering investment decisions - and continue to be so. For this reason, I studied the policy documents of the state and politicians', bureaucrats', and global and national mining capitalists' discourses on the expansion. The analysis of these below illustrates the 'processes though which capitalists and statemachineries map, identify, quantify, measure, and code human and extra-human nature in service to capital accumulation', an analytical and descriptive task that M oore $(\underline{2014}, 3)$ sees as the fundamental missing piece in most of prior $M$ arxist theorizing on how capitalism is created. The discourses below are expressions of the historical conditions underlying the boom.

\section{The Role of Government}

The official policy that has boosted expansion can be summarized in the following statements by the Finnish government. The first document is the new Arctic strategy of August 2013. Business interests, especially the export of mining technology and the opening up of the Arctic for accelerated resource extraction, are central: 'Finland is a forerunner in sustainable Arctic mining. ... For Finnish actors the development opens up new international business possibilities both in mining technology and increasing transportation in the Arctic area, for example in the need for icebreaker utilities. ... The goal of Finland is to get more foreign investments into the growing mining sector.' (Suomen arktinen strategia 2013, 9, 29-30, translated by the author). 
Second, Finland's M inerals Strategy (TEM and GTK 2010, 2, 13, 17) outlines the policies required to reach the vision for 2050, when 'the minerals sector is [envisaged to be] one of the key foundations of the Finnish national economy. [An action proposal for] securing the supply of raw materials [is that] ... permit processing times are significantly reduced.' The aim is to mine 70 million tonnes of metallic ores by 2020 . This Government Strategy was written by mineral-sector personnel: all the 20 specialists were either business or state pro-mining persons.

These 'strategies' are expressions of how capital needs to make a 'spatial fix' (in terms of Harvey $\underline{2003}$ ) to secure a continued accumulation. To achieve such an $\mathrm{M}-\mathrm{C}$ cyclic boost in accumulation requires the prior reworking of symbolic-space power relations; that is, ideological constructs that work as 'cultural fixes'. M oore $(2014,16)$, building on Shapiro's concept of the 'cultural fix', argues how this is a 'necessary symbolic condition' for the appropriation of the Four Cheaps. The techno-utopian and neo-liberal ideology prevalent in the key policy documents above has served as a 'cultural fix' in symbolic space, normalizing otherw ise unacceptable appropriation of nature to create cheap raw materials. When they are portrayed and conceived as unlinked to power relations, these normalizations are symbolic violence: the damage caused to nature, and the creation of class inequalities by 'spatio-cultural fixes'.

These pro-mining discourses can be considered as part of what Moore $(\underline{2014}, 21)$ calls 'capitalism's correspondence project', the aim of which is to create a 'universe of "economic equivalence" ' in all corners of the world - this expansion of global capitalism meaning that the astounding geographical differences of even the Arctic and the Tropics are rendered flat. In this flatness-making process, it is essential to deny particular cultural notions given to places, to combat notions of the 'nature of Lapland' or 'Arctic beauty' by turning such localities into abstract spaces of calculable extraction: instead of talking about (a piece of) Lapland being extracted, we start to speak of a mineral ton being excavated. In Bourdieu's (1991) terms, these ideological manoeuvres create objectified symbolic capital.

The creation of objectified symbolic capital is the mechanism through which a direct link and interchangeability are created between physical and symbolic spaces: this tool of space-linking can be used also by those resisting appropriation of land (and has been used by, for example, Landless M ovement activists in making land sacred in Brazil and re-symbolizing capitalist land uses) (Kröger 2010, 2013a). Land, minerals and water are the central objectified symbolic capital in mining conflicts, as it is through their symbolic stability, public acceptance and legitimacy, of how they are used, that the maintenance or decline of the land-, mineral- and water-devouring mining investment model depends. If perplexity and discussion of the objectified symbolic capital start to take place on a socially significant scale, this will call the value of capital into question. The effectiveness of land holding and expansion thus depends on the framing of key objectified symbolic capital; that is, on our ways of knowing.

'Cultural fixes' are battles in the symbolic space, if there is resistance to the new ideologies - and this has been the case in Finland, in the form of 'counter-cultural fixes' coming from the two poles of a Polanyian organic society (the progressive state and civil society). The National Audit Office of Finland prepared a special Audit Report (number 154) in 2007 (no page numbers in the English abstract, quoted below) on the state's role in booming mining activities, covering possible conflicts of interest and wrongdoings. The report was very critical, pointing out great flaws in the old mining law in the new global setting. The comments from the report even suggest that a type of regulatory capture has occurred in Finland, first as the autonomy of the bureaucratic apparatus has become contradicted by its strong midwifery role:

On the basis of the audit, there are several conflicts of interest ... The M inistry of Trade and Industry markets Finland as an excellent place for mining operations and promotes exploration and mining in various ways. ... [this] endanger[s] its objectivity and independence as a licensing authority. ... supervisory 
tasks related to claims and mining operations have not been handled properly. (National Audit Office of Finland 2007)

According to the Audit, the state has invested extensively in exploration, but the information generated has ended up in the wrong hands or been lost. The mines have not been properly monitored, and companies have been given a free hand to speculate and hold deposits illegally. Environmental damage (in the form of the proliferation of waste rock) has also been encouraged by these practices.

The Audit also studied whether the authorities act in such a way that the social benefits of the exploitation of minerals are maximized. This issue is related to the debate on whether the new mining investment is an economically sound policy, or whether it should rather be considered as an Arctic extension of the global 'land grab' phenomenon, in which arguments about growth in jobs and GDP are used to usher in changes in land control (yielding benefits to a select few), the latter supposition gaining support:

The audit made findings that suggest that mineral resources are in fact limited.... On the basis of the audit, companies have been able to engage in mining operations partly at others' risk.

The Audit found that the authorities' activities have not been effective enough and that 'negative impacts and stakeholders have not received adequate attention'. It is important to remember that most of the findings of the Audit still apply, as most mines operate under the problematic old M ining Act. Particularly important are the Audit notes on state-landowner relations, whereby the state policy has encouraged a corporatization of land by obliging landowners to sell land to companies, this being the best option for receiving at least some compensation (a landowner cannot influence a mine-opening decision):

Landowners' possibilities to protect their interests in the mining process are poor, partly because of the need to protect interests for decades and in different processes. Furthermore different kinds of compensation and charges are based on legislation that is quite open to interpretation, and these are set following different procedures or must be negotiated with the mining company. ... payments have substantially lost their significance as compensation for lost proceeds. (National Audit Office of Finland 2007)

This official Audit Report has not been taken into serious consideration. All these factors illustrate a strong pro-mining state midwifery role that has boosted unchecked expansion that benefits mining capitalists. The mapping, identifying, quantifying, measuring and coding of the 'Finnish mining potential' by global company executives, discussed below, has fitted together well with this government policy line, both parties benefiting from each other's discourses to push through changes, and assuring a scale-linkage.

\section{The Role of Global Investors}

Global investors have played a fundamental role in the boom, providing capital. In the Fraser Institute's $\underline{(2013})$ survey that set out the attractiveness of different countries for mining bosses, Finland ranked very high, globally, in several regulatory categories. These neo-liberal regulatory enablers of the boom included the following:

- the current mineral potential, assuming current regulations and land-use restrictions (second, after Greenland);

- the tax regime (third, after Yukon and Alberta);

- socioeconomic agreements/community development conditions (third);

- trade barriers - tariff and non-tariff barriers, restrictions on profit repatriation, currency restrictions and so on (fourth); and 
- labour regulations, employment agreements, and labour militancy or work disruptions (fourth).

Besides these neo-liberal regulatory enablers, the boom has also had several drivers. The boom was driven by the Finnish state's ability and willingness to offer the following services, which are supportive of mining capital, to companies at lower cost and/or better quality than most other states:

- geological database (including the quality and scale of maps, ease of access to information, and so on - first);

- supply of labour/skills (first);

- composite policy and mineral potential (second, after Yukon);

- $\quad$ political stability (third); and

- infrastructure (including access to roads, power availability and so on - seventh).

Finland also ranked first in the Fraser Institute's 2014 survey, published in 2015.28 The global view of Finland is extremely positive, and emphasizes issues not mentioned in the government 'strategies' above: low land-use restrictions, low levels of taxation, low levels of compensation required for local community development (including very low or non-existent royalties), and low restrictions on profit repatriation. All these points suggest that power in, and control of, space are biased towards corporations. The viewpoints above suggest that global capital recognizes this lopsidedness, but that the most important national decision-makers do not (or do not want to) recognize this. In contrast, the orthodox state/industry viewpoint - the pro-mining view - emphasizes price hikes, development of technology, good infrastructure and political stability as the key drivers behind the expansion. They do not mention the role of hierarchized power relations and capital asymmetries as drivers - and thus boost the symbolic capital of mining.

The global investors' view, like the government discourse, can also be considered a 'cultural fix' promulgated by mining capitalism to redefine countries by 'mapping their potential'. This fix helps subsystems, such as national symbolic systems whose key actors share their principal ideas with global capitalists, to realign themselves as subsystems of the particular global system they want to become part of. Finnish politicians and the state's Arctic policies have not camouflaged the great eagerness in participating in the appropriation of Arctic natures, 29 an eagerness that requires a deeper analysis of cultural values that need to be understood.

\section{'Siting Cronyism' and 'The Myth of Efficiency and Techno-Utopianism' as Boom Enablers}

The tumultuous political dynamics in the mining sector are part of the larger Finnish land-use policymaking, the murky aspects of which have started to become more visible in recent years. Investigative journalists have shed light on 'Finnish corruption' that happens below the radar and thus is not revealed in international comparisons of transparency. In this 'way of the country', a small circle of well-placed decision-makers make land-use policies based on their connections, bonds and affiliations, thus deciding who will get plots, who can start to develop projects on these sites and who will then become wealthy in the end. In such a setting, which is increasingly seen as a form of cronyism, critical voices are not heard or criticism is not offered, and alternatives are typically not considered, before it is too late. This web of ties in the socio-political sphere also links with ideas governing symbolic valuation in the 'Finnish' symbolic space, such as the valuation of 'efficiency'. To be 'efficient' is considered as part of being a good Finn in a Finnish myth of Finnish people who are 'hard-working', 'industrious' and 'productive'. This symbolic space-making has contributed to hasty mining licencing, revealing how easily short-term 'efficiency' and busy-ness can turn into long-term inefficiency. This efficiency-reasoning in which corners are cut is a type of national delusion. 
'Siting cronyism' and 'corner-cutting efficiency', while in effect ordering the social and symbolic spaces, respectively, have made it possible for perilous projects that should have undergone deeper scrutiny, and whose potential benefits should have been more democratically distributed, to go through the system unnoticed. These are enabling, but not driving space-making mechanisms, since as long as the proposed projects are 'good' in the sense of distributing benefits more widely by their very nature, and lack the possibility that they might go badly wrong (in the environmental sense, not having even the possibility of major leakages, for example), the flaws in these practices can go unnoticed.

The proponents of mining also believe that problems can be fixed by the appropriate technology - which Finns, given their efficiency, can develop, Finland being too advanced politically and technologically to repeat the errors and disasters that other countries make. This is a sort of techno-utopianism coupled with smugness and arrogance that has permeated the national symbolic space, and can thus be effectively used as an enabling factor particularly in ushering in 'large-scale', 'pioneering', 'pilot', 'green', large-promise and unsure projects and technologies.

\section{Developmental Remarks: A World-Systemic Perspective to Neo-Extractivism}

What does this case tell us about world-historical changes in the capitalist world-system, and the role of national resource booms in core-periphery dynamics? From the seventeenth century onwards, SwedenFinland was given the role of a bulk commodity producer for the war economies of Europe, leading to a drastic increase in the production of potash, tar and other wood-based products in particular (M yrdal 2007): Finland became an exploited colony of the Swedish empire and its rural areas peripheries in the world-system. As of the nineteenth century, logging for the export of potash and tar had ravaged large forest areas, equivalent in size to that lost through slash-and-burn agriculture (Kunnas 2007). Potash export peaked in 1820-40, but declined close to nil with the rise of a strong domestic forest industry, which found better uses for wood. Instead of exports, the 'comparative advantage' in appropriating cheap raw materials was used for the building of globally competitive and leading economies of scale and technology in woodprocessing (Kröger 2013b), which allowed an escape from the false promise of growth via commodity exporting, promulgated by rising global hegemons to would-be countries of servitude up to the present day (Bunker and Ciccantell 2005). By the 1980s, Finland had consolidated its position in the core of global capitalism.

Prior to 1995, mines were state-owned: most pre-boom Finnish mining was based on Outokumpu's major copper deposit, found in the 1910s and depleted by 1989 (Kuisma 1989). But currently Finland is increasingly resembling a colony in Walker's (2001) depiction of different systems, given its capture-based mineral law, with no extra taxes for outside resource monopolizers: the country's mineral wealth is rightly seen by multinational capital as free to be taken, and no closed circuits of capital pumping to other sectors by locally accumulated mining capitalists, as in California, are to be expected. The capital created by the 39-52 per cent profit rates recorded by two Canadian mining companies in Finland (see Table 1 ) are exported, and not reinvested in the Finnish political economy's non-mining sectors.

Politicians argue that the state does not have the capital to extract the minerals, for which reason foreign corporations are given the deposits for free; but they still are willing to provide hundreds of millions of euros for the building of a road that will serve for only about two decades, and other infrastructure projects (e.g. the Norwegian Yara in Sokli phosphate mine project) that these foreign corporations demand in order to open up the mines and export the minerals. In the light of modern development theory informed by experiences in the Third World, there is something deeply vexing and incomprehensible in this policy, something for which I have not been able to find a reasonable explanation. The discourse of job creation, the creation of any number of jobs at any price by a private enterprise, seems to currently override any other reasoning in the public discourses of most politicians. This demonstrates how it is not sufficient to 
explain how the creation of capitalist class inequalities boosts the appropriation of nature, and that the role of symbolic cleavages and power relations must be considered. This is why I have offered a new theory of spatial analysis to help explain causalities in resource rushes and other land-use changes.

M ining will have more negative than positive impacts in Finland, also because of the damage mining does to the traditional forest-dependent industries and cultures, including reindeer herding, which is a billioneuro business in many proposed mining areas of Lapland. M ining and its ancillary industries have a long predatory relation with forests (Walker 2001), and this is no different in Finland, where mining and exploration royalties paid to landowners are not large enough to compete with forestry yields (Arajärvi 2013) or even with returns from reindeer herding or tourism, particularly if the time span is 40 years plus, rather than two or three decades.

This analysis supports M oore's (2014) claim that the exploitation of paid labour (e.g. the creation of jobs) can only be increased at a level lower than the appropriation of unpaid work: in capitalism, if new paid jobs are to be created, unpaid work (including that by extra-human nature) must be appropriated at a faster rate than capitalization. In many senses, the Finnish state escaped this capitalist dynamics, or reduced its impact, during the twentieth century - partly by casting the damage of appropriation on to other countries that were starting to serve the interests of new national industries (Kröger 2013b), and partly by modelling a Nordic welfare state that places limits on capitalism. As neo-liberalism has eroded the basis of embedded liberalism, and the global land rush and the rise of new global powers with neomercantilist agendas is transforming the situation into one in which, for example, a hectare of land in Brazil to be bought for planting eucalyptus costs more than standing forestland in Finland, it has become much harder to adhere to the policies of maintaining a welfare state and externalizing cheap natures.

\section{Conclusions}

This study has considered the causal condition complexes behind the new Arctic resource rush, based on an analysis of existing official data and new field research material collected during 2013-14 on the Finnish mining boom that started in around 2005. The case was used to develop and put to work new concepts explaining how inter- and intraspatial hierarchizations and relations drive and enable resource rushes. $A$ hypothesis that the boom has been based on a simultaneous social space hierarchization and symbolic capital enjoyed by mining capitalists was examined by combining the available evidence from expansion projects with policy documents and interviews with key policy-makers. The findings provide support for the hypothesis.

As a causal explanation, the lopsided capture of mineral resources by private groups and key industry persons, aided by bureaucrats and lax regulation, and cemented by a trust and honour that the new mining capitalists enjoyed as 'wealth and job-creators' in the pre-boom symbolic space, has received considerable support. A general transformation from a welfare to a competitive neo-liberal state can be considered one of the causal conditions that made the boom possible; 30 the entrenchment of class relations assisted in the privatization and foreignization of major mineral deposits and left the expansion unchecked, leading to environmental disasters and a democratically problematic expansion trajectory. The Talvivaara case and other revolving doors, along with privatization schemes and the narrow base of expertise, support the hypothesis: it can be argued that mines and deposits that were formerly publicly owned, along with the regulatory body, have been partially 'grabbed' in this sense. Along the same lines, based on an examination of the history of Talvivaara's uranium permit applications since the 1970s, Flöjt and Flöjt (2012) argue that pro-mining politicians, bureaucrats and businesspeople have knowingly misled the public and issued irregular permits that have not taken into account the true extent and impacts of uranium mining taking place alongside nickel extraction at the site. Such cases of severe transparency problems between the public and authorities, coupled with the revolving doors problem, exemplify how the traditional rules of 
symbolic space, with trustworthiness and a low level of corruption considered cultural traits and common meritorious symbolic acts in Finland, have become increasingly sidelined. This has happened through the creation of symbolic capital derived from concentrated capital in social space and maintained through misrepresentation of the mining boom as a job-creating, self-regulating and 'green mining'-based developmental project (visible in the portrayals of the boom by, for example, President Niinistö as 'Finland's new Nokia'), $\underline{31}$ these legitimizing discourses hiding the real character of the boom as based on the appropriation of nature and the giving away of national mineral wealth to multinationals for free.

Three causal conditions gained most support among the boom explanations given by the interviewed policy-makers (the summaries below are created based on the formulations offered by the informants; each point includes the views of both those considering the expansion more critically and those who were pro-mining, but the large bulk of informants were bureaucrats with no clear political viewpoint on the expansion, and these answers are also reflected):

- The ability to benefit from 'a lax old Mining Act' (in the pre-2011 period) during a global commodity boom that opened up international capital markets for ventures by mining specialists, including speculative investing and investment that relied on insider knowledge on the part of 'mining elites'.

- 'Large scale political support' marketed mining projects' (rural) 'job-creation as one of the only options for retaining living standards in a time of a structural economic transformation', within a state paradigm change to one of competition, wherein positive accounts of Finnish mining potential by global investors partially encouraged politicians to create policies that allowed for expansion.

- A capture-based exploration system providing great security of tenure, even against possible critics (landowners or other stakeholders having no voice or way to stop a project under the old law), which allowed for 'exceptionally good investment opportunities'. After the boom had already started, the state 'liberated extensive geological databases' it had created 'during 100 years of costly state geological surveys', making the boom faster and wider.

In sum, those with knowledge about (a) free access to turn well-mapped mineral resources into private property and (b) the possibility of attaining substantial funds from international mining investors utilized their connections to produce a major hierarchization of class relations in the social space. The result, a new top social stratum of mining capitalists, brought about the mining boom that altered landscapes. This physical change was supported by securing favourable content in symbolic space, wherein the lure of 'mining jobs' was used as a key counter-argument against heterodox criticism. 32 These findings also support the theoretical argument that the existence and agency of middlemen with exclusive information and connections, allowing them to link local lands with global capital (Sud 2014), is a necessary condition for land rushes to occur.

Those accustomed to seeking an increase of capital via mining saw that their window of greatest opportunity, opened up by commodity price increases, was closing as the National Audit Office of Finland (2007) and other concerned parties recognized the need to update legislation and execute policies according to the existing laws. They were about to take this action quite so on, thus severely curbing the possibility of acquiring an elite class position in social space on the basis of drastically changing physical space (via mining), through a geographical scale-linking of the Finnish possibility of free appropriation of nature with global mining capital in search of new peripheries.

The new global commodity paradigm, where even the global economic slowdown of recent years has not brought commodity prices or capital expenditures back to a business-as-usual situation, suggests that this is not just another conjuncture, but a completely new situation, in which these 'cheap' natures are becoming 
harder to create. This in itself explains why there is such a rush by the most-capitalist actors to pursue the opening up and securing of the remaining resources as quickly as possible - the lack of understanding of the situation as a paradigmatic change explains why politicians still operating under 'Basics in M acroeconomics' support these ventures. Although the Nordic and Arctic regions are relatively marginal and will require large spatial barriers in extraction and logistics to be overcome, these are also the regions that offer the globally most-welcoming political atmosphere and pro-extraction tenure and legal settings (which the local resistance and progressive-nationalist states in the Global South increasingly do not provide): it is precisely to these regions that global mining capital has turned its head, seeing deeper and further into the future than the busy politicians who care more about GDP figures and private profit than long-term socio-environmental well-being

The key drivers of the new 'conquest of nature' by mining in Finland (to paraphrase the first book on environmental history in Finland, published by IImo M assa in 1994 and called Pohjoisen luonnonvalloitus [The Conquest of Northern Nature]) have been the identification and appropriation of unpaid work (including extra-human natures) by the creative acts of capitalists and state machineries, such acts being, according to Moore (2014), requirements for the production of the 'cheap natures' through which capitalism expands. These are historical expressions of a significant enlargement in the zone of appropriation by global capitalism by means of an Arctic land rush, which will be, necessarily, a short-lived trick, as will become evident once the attempted creation of cheap raw materials by expanding appropriation faster than exploitation becomes visible in the form of empty pits and leftover tailing ponds, leaking out the costs of accumulation. The running out of cheap natures has al ready started to become visible: in the Finnish metal mining boom, for every profitable mine there emerged two seriously unprofitable ones (see Table $\underline{1}$ ).

The unfolding trajectory of the proposed Sokli phosphate mine and other uranium-producing projects, where the general public, local people or critical experts are still not consulted, but are sidelined by politicians pushing for expansion in spite of all the problems and the new law that requires consultation, suggest that the future will not offer a more democratic or sustainable use of natural resources. 33 Instead, it is more likely that this phase of history will be remembered as one when the bases were laid for a fast and disruptive appropriation of Arctic 'Cheaps' as capital's last-ditch attempt to expand through an M-C cycle of accumulation.

These developments will have considerable consequences globally, as any mining model - including yields, technology complexes and capital - created in one country's boom will influence other countries to which capital turns its attention for new speculative and high-expectation growth rates. This applies particularly to Finland, with its major global industry presence in the field of mining technology, and its key position in the future of Arctic development.

\section{Footnotes}

'Arctic' is defined here as referencing the Nordic countries, Canada, the United States (US) and Russia, as all of these nations consider themselves to be at least partly Arctic.

2

Drawing on M arx, Arrighi (1994) argues that capitalism has two phases of expansion: money capital (M) and commodity capital, or increase in trade of commodities of all sorts $(C)$ (often requiring territorial expansion). Once capital is over-accumulated within a marked territory by technological development, 
innovation or increased money capital made in financial deals, and can no longer maintain high levels of returns, a need arises to invest capital and capture resources through territorialization that increases the possibility of gaining commodity capital, or uses commodity trade to make more of money capital, the ultimate goal in capitalism. It is notable that the Finnish mining boom started a few years before the 2008 financial crisis, and was deepened after it. This shows how a period of systemic (global) financial expansion boosts regionally specific 'material expansion' in a way that targets new territories.

3

I follow Wright's $(\underline{2005}, 14)$ conceptualization of class relations as 'unequal rights and powers of people over economically relevant assets'.

\section{4}

For example, legal changes allowing for foreignization of land control was a part of the 1990s neo-liberal transformations; foreign ownership of mines was made possible in 1994 (National Audit Office of Finland 2007).

5

The Finnish capture-based mining expansion system signifies very low land costs to companies. Drawing on Harvey's (2003) theorization, land costs are perhaps the most important definer of whether or not a territory is peripheral to global capitalism. Higher land prices, which are a sign of less peripheral settings, act as a barrier to accumulation by dispossession, which is, by definition, interested primarily in seizing control of assets at zero or low cost (Harvey 2003).

6

However, on 5 December 2014, the Parliament approved a new energy tax that hits energy-intensive mining operations in particular (that is, underground mines, not the much more conflictive and problematic open-pit mines of the new boom), increasing the taxes on mining by about $€ 20$ million per year, which is about 1.2 per cent of the sector's turnover (http://www.taloussanomat.fi/perusteollisuus/2014/12/08/kaivosala-pettyi-energiaveroon-hassupiirre/201416895/12; accessed 17 June 2015).

7

As the Fraser Institute $(\underline{2013}, 11)$ notes: 'While geologic and economic evaluations are always requirements for exploration .... a region's policy climate has taken on increased importance.'

8

Illustrating the peak of the mining boom when new mines, particularly open-pit mines, were being opened, waste-rock mining in metal mines reached over $26 \mathrm{M} \mathrm{t}$ in 2010, rising from only $1 \mathrm{Mt}$ in 2005 (GTK 2013). The share of mining in Finland's industrial production was about 1.5 per cent in 2012. The turnover of the metal-mining sector has increased five-fold between 2005 and 2014 (http://www.stat.fi/til/tti/index.html, accessed 17 June 2015; M inistry of Employment and the Economy 2014). Finland, Sweden and Poland are by far the most important mining regions of Europe, and Finland has the most diversified mineral portfolio of these (http:// www.bothniangreen.se/wp-content/uploads/2012/12/\%E2\%80\%93-New-boost-forEuropean-industrial-future.pdf; accessed 17 June 2015). 
Sokli is now owned by the Norwegian company Yara, to whom the state sold its shares ( $30.05 \%$ of capital) in the Kemira Growhow company in 2007 for only $€ 207$, Kemira Growhow owning the Rautaruukki statecompany found reserves until then (http://mita-olisi-tutkittava.blogspot.fi/2008/09/growhow-liian-suurierehdys.html; accessed 17 June 2015).

10

Table 1 provides data on the taxation of metal mining companies. In 2013, only two companies can be said to have been taxed: Agnico Eagle was taxed €11.6 million, and Pyhäsalmi mine (First Quantum Minerals) $€ 1.7$ million.

11

For the cultural, economic, social and symbolic capital, the identification of these heuristic devices as analytical and empirical categories flows from Bourdieu (1986, 1991, 1998); social space includes social positions, particularly class relations and other positions of power that economic, cultural and social capital offers, but also social acts that change these. Physical space-change signifies, for example, landscape or bodily changes, material changes in use of nature - this is the dependent variable here. Redistribution of power in symbolic space occurs through a different logic. When differences in capital are misperceived as differences in honour, they function as what Bourdieu calls symbolic capital, which also functions as symbolic violence $(1991,238)$. If the symbolic power of those in favour of mining is diminished - that is, their honour and their classification as agents of rightful, merit-based or natural development come to be perceived as merely based on the control of greater amounts of social, economic and/ or cultural capital than those from whom space is taken - then their pow er to expand extraction also lessens. Besides symbolic capital-changes, meritorious symbolic acts can also be used to change symbolic power relations. Symbolic power is 'the power to constitute the given by enunciating it, to make people see and believe, to confirm or transform the vision of the world, and thereby action upon the world, and thus the world itself' (Bourdieu 1991, 170) and its content is ideas.

12

Some notable exceptions remained, such as the world-class chromite mine in Kemi that serves the nearby Outokumpu steel production complex.

13

M ost of the current Finnish mining operations and projects are ex-properties of Outokumpu, and the new foreign companies owning the deposits now have ex-Outokumpu bosses as their key directors: such mines, with both a physical and social-space continuum with Outokumpu, sliding from public to private ownership, include, for example, Talvivaara, Belvedere Resources, Dragon Mining, Nordic M ines and Altona Mining (Rytteri 2012).

14

On 31 March 2009, Perä owned 25.44 per cent (www.talvivaara.com; accessed 17 June 2015).

15

http://www.hs.fi/talous/a1415341178557 (accessed 17 June 2015).

16

http://www.hs.fi/talous/a1415341178557 and http://www.hs.fi/talous/a1383806203079 (accessed 17 June 2015). 
17

http://yle.fi/uutiset/four charged in talvivaara toxic leak case/ 7485070 (accessed 17 June 2015).

18

http:// www.kaleva.fi/uutiset/talous/rothovius-talvivaarasta-osakkeenomistajia-johdettu-systemaattisestiharhaan/680614/ (accessed 17 June 2015).

19

http://yle.fi/uutiset/government_confirms plans to sink $112 \mathrm{~m}$ more in talvivaara/8082227 (accessed 17 June 2015).

20

One informant explained that the mining infrastructure, including repair and construction hubs and railroads, once established, will lead to the accelerated excavation of the weaker deposits as well, and thus to a faster and more powerful boom.

21

According to an industry expert, M etso, Outotec, Konecranes, Ramirent, Parkkola Conveyors and Tapojärvi are among the most important Finnish mining technology firms that have benefited most from the boom and are behind it; the cluster has significant global presence; for example, approximately 75 per cent of the Arctic mines utilize Finnish technology and about 80 per cent of the world's new underground mining technology originates from Finland or Sweden.

22

The share of metal ore exports has increased with the boom from about 2,000 tons to about $0.173 \mathrm{Mt}$ between 2005 and 2013, the value of export in 2013 being $€ 126.5$ million. New projects, such as the plan to extract the massive Sokli phosphate-uranium deposit by the 40 per cent Norwegian state-owned Yara will export all phosphorus to Norway for processing. In the report of the Ministry of the Employment and the Economy (2014), resource nationalism and protectionism, which have arisen in the Third World in particular, are seen as a threat to Finland, whose ore-processing facilities rely mostly on outside minerals (being self-sufficient only in chrome): this might explain why the state pursues a rather liberal flow of natural resources in its national and global policies.

\section{3}

A key bureaucrat mentioned that the goal of creating companies and employment is in contradiction with environmental values, both of which are supposed to be governed by the new ELY Centres for Economic Development, Transport and the Environment. All Environmental Impact Assessments (EIAs) were approved between 2010 and 2013 by the authorities. RSAA is the acronym for Regional State Administrative Agencies.

\section{4}

State information was freed to the public domain after the start of the boom, merely accelerating rather than explaining its start, argued one informant. Almost all projects are based on these state-found deposits. 
http://www.stat.fi/til/yrti/2013/yrti_2013_2014-12-18_tie_001_fi.html (accessed 17 June 2015). The average profitability rates of other economic sectors in Finland were 3-12 per cent

(http://www.stat.fi/til/yrti/2013/yrti_2013_2014-12-18 kat_001_fi.html; accessed 17 June 2015).

26

11 February 2014, http://www.zygomatica.com/wp-content/uploads/2014/02/Talvivaaran-saneerauksenpiiloriskit selonteko 11-02-14.pdf (accessed 17 June 2015).

27

According to my informants, this contentious agency by the Sámi has so far prevented mining expansion in northernmost Finland. However, new mining projects are also in the pipeline there, and some have already received exploration permits, such as Karelian Diamond Resources, an Irish company, for exploration inside the Kevo Strict Nature Reserve (Haataja 2014).

28

All the other positions in the top ten went to regions in Canada, the US or Australia (http:// www.fraserinstitute.org/uploadedFiles/fraser-ca/Content/researchnews/research/publications/survey-of-mining-companies-2014.pdf; accessed 17 June 2015).

29

http://yle.fi/uutiset/finland looking to supply icebreakers to russia/ 6820367 (accessed 17 June 2015) and http://yle.fi/uutiset/suomi mukaan_arktiseen_oljynporaukseen/5069830 (accessed 17 June 2015).

30

The neo-liberalism of the past 25 years has not only hierarchized the class relations of social space, but has introduced new symbolic capital for capitalists in the symbolic space; neo-liberal cuts to welfare state functions in rural peripheries have also supported the mining boom by driving urbanization, cutting alternative jobs in rural areas, and thus also delimiting the propensity and number of critical voices in areas portrayed as 'in need of jobs at any cost'.

31

http://www.kaleva.fi/uutiset/pohjois-suomi/niinisto-kaivosten-valvonta-on-riittavaa/573070/ (accessed 17 June 2015).

32

http://yle.fi/uutiset/ministerion kaivostutkimukset_eparealistisia/5965664 (accessed 17 June 2015). 33

http://yle.fi/uutiset/soklin_lupakasittely_kestaa_viela_vuosia/ 7648823 (accessed 17 June 2015).

\section{References}

Arajärvi, N., 2013. Louhintakorvaukset Suomen kaivoslaissa (621/2011) ja kaivosrojaltien kansainvälinen vertailu [M ining Compensation in Finland's M ining Act (621/2011) and International Comparison of M ineral Royalties]. Master's thesis, Forest Resource and Environmental Economics, University of Helsinki:

Arrighi, G., 1994. The Long Twentieth Century. London: Verso. 
Bebbington, A., ed., 2012. Social Conflict, Economic Development and Extractive Industry: Evidence from South America. London: Routledge.

Bourdieu, P., 1986. 'The Forms of Capital'. In Handbook of Theory and Research for the Sociology of Education, ed. J. Richardson, 241-258. New York: Greenwood.

Bourdieu, P., 1991. Language and Symbolic Power. Cambridge: Polity Press.

Bourdieu, P., 1998. Practical Reason: on the Theory of Action. Cambridge: Polity Press.

Bunker, S. and P. Ciccantell, 2005. Globalization and the Race for Resources. Baltimore, M D: Johns Hopkins University Press.

Edelman, M ., C. Oya and S.M. Borras Jr, 2013. 'Global Land Grabs: Historical Processes, Theoretical and M ethodological Implications and Current Trajectories'. Third World Quarterly, 34 (9): 1517-1531.

Ernst \& Young, 2013. 'Business Risks Facing M ining and M etals 2012-2013', http://www.zurichna.com/internet/zna/SiteCollectionDocuments/en/Products/energy/Ernst_Young_Mining Risk Survey.pdf (accessed 17 June 2015).

Evans, P., 1995. Embedded Autonomy: States \& Industrial Transformation. Princeton, NJ: Princeton University Press.

Flöjt, M. and L. Flöjt, 2012. Kysymyksiä Talvivaarasta: uraani ja lupakysymykset [Questions about Talvivaara: uranium and permit questions]. Books on Demand.

Fraser Institute, 2013. Survey of M ining Companies, http:// www.fraserinstitute.org/uploadedFiles/fraserca/Content/research-news/research/publications/mining-survey-2012-2013.pdf (accessed 15 December 2014).

GTK (Geological Survey of Finland), 2013. Malminlouhinta, http://uusi.gtk.fi/export/sites/fi/geologia/_kuvat/uusi_metallimalminlouhinta2000_2012.pdf (accessed 15 December 2014).

GTK (Geological Survey of Finland), n.d. 'Kaivokset ja ajankohtaiset tutkimuskohteet', http://www.gtk.fi/ajankohtaista/media/tietoa toimittajille/kaivostoiminta/index.html (accessed 17 June 2015).

Haataja, A., 2014. Finnish Colonization - Irish Invasion, http://anttihaataja.wordpress.com/2014/05/25/finnish-colonization-irish-invasion/ (accessed 15 December 2014).

Harvey, D., 2003. The New Imperialism. Oxford: Oxford University Press.

Helsingin sanomat, 2012. 'Environment M inister Lashes Out at "Arrogant" Mining Companies', 4 M ay. Kaleva, 2012. 'Ympäristötarkastaja hyppäsi virkavapaalla vastapuolelle' [Environmental Inspector Jumped to the Opposing Side during an Off-Duty Period]), 21 April.

Kantola, A. and J. Kananen, 2013. 'Seize the M oment: Financial Crisis and the Making of the Finnish Competition State'. New Political Economy, 18 (6): 811-826.

Klare, M., 2012. The Race for What's Left: The Global Scramble for the World's Last Resources. New York: Metropolitan Books. 
Knus-Galán, M ., 2013. 'The Billion Dollar M ining Experiment'. ICIJ, 18 December, http:// www.icij.org/blog/2013/12/ billion-dollar-mining-experiment (accessed 17 June 2015).

Kröger, M., 2010. The Politics of Pulp Investment and the Brazilian Landless M ovement (M ST). PhD thesis, Acta Politica 39, University of Helsinki.

Kröger, M ., 2013a. Contentious Agency and Natural Resource Politics. London: Routledge.

Kröger, M ., 2013b. 'Globalization as the "Pulping" of Landscapes: Forestry Capitalism's North-South Territorial Accumulation'. Globalizations, 10 (6): 837-853.

Kröger, M., 2014. 'The Political Economy of Global Tree Plantation Expansion: A Review'. J Jurnal of Peasant Studies, 41 (2): 235-261.

Kuisma, M., 1989. A History of Outokumpu. Gummerus, Jyväskylä.

Kunnas, J., 2007. 'Potash, Saltpeter and Tar: Production, Exports and use of W ood in Finland in the 19th Century'. Scandinavian J ournal of History, 32 (3): 281-311.

M ining Act (621/2011). Finland. Helsinki, 10 June 2011, http:// www.finlex.fi/en/laki/kaannokset/2011/en20110621.pdf (accessed 17 June 2015).

Moore, J., 2014. The Capitalocene II, http://www.jasonwmoore.com/uploads/The Capitalocene_Part II_ June 2014.pdf (accessed 17 June 2015).

M yrdal, J., 2007. 'Food, War, and Crisis: The Seventeenth Century Swedish Empire'. In Rethinking Environmental History, eds A. Hornborg, J.R. M cN eill and J. Martinez-Alier, 79-98. Lanham, M D: AltaM ira Press.

National Audit Office of Finland, 2007. The State as a Promoter of Exploration and M ining. Performance Audit Report 154.

Nimtz-Köster, R., 2012. 'Klondike in Lapland: Mining Companies Swarm to Finland's Far North'. Spiegel Online International, 2 November, http:// www.spiegel.de/ international/business/ mining-boom-underwayin-finland-in-the-search-for-mineral-deposits-a-864561.html (accessed 17 June 2015).

Patomäki, H., 2007. Uusliberalismi Suomessa [Neoliberalism in Finland]. Helsinki: WSOY.

PwC, 2012. The Finnish M ining Industry. An Overview - 2012, https:// www.pwc.fi/fi/julkaisut/tiedostot/pwc-mining-overview-october2012.pdf (accessed 17 June 2015).

Ragin, C. and S. Strand. 2008. 'Using Qualitative Comparative Analysis to Study Causal Order: Comment on Caren and Panofsky (2005)'. Sociological M ethods \& Research, 36: 431-441.

Rytteri, T., 2012. 'Social Responsibility Strategies and Social Expectations of Mining Firms Operating in Finland'. Alue ja ympäristö, 41 (1): 54-67.

Sud, N., 2014. 'The Men in the M iddle: A M issing Dimension in Global Land Deals'. Journal of Peasant Studies, 41: 593-612.

Suomen arktinen strategia, 2013. 'Valtioneuvoston periaatepäätös 23.8.2013', http://vnk.fi/documents/ 10616/1093242/]1413 Suomen tarktinen+strategia. pdf/ 1939b230-2dfb-4a6692e9-e765b6dd7086? version=1.0 (accessed 17 June 2015). 
TEM (M inistry of Employment and the Economy, Finland), 2012. Suomen kaivosteollisuuden tilannekatsaus vuonna 2012, https:// www.tem.fi/files/34066/TEM rap_23_2012.pdf (accessed 17 June 2015).

TEM (M inistry of Employment and the Economy, Finland), 2014. [M ining] Sector Report 2/2014 (author: M. Kokko), http:// www.temtoimialapalvelu.fi/files/2253/Kaivosteollisuus_marraskuu_2014.pdf (accessed 15 December 2014).

TEM (M inistry of Employment and the Economy, Finland) and GTK (Geological Survey of Finland), 2010.

Finland's M inerals Strategy,

http://projects.gtk.fi/export/sites/projects/minerals strategy/documents/FinlandsM ineralsStrategy 2.pdf (accessed 17 June 2015).

Tukes (Finnish Safety and Chemicals Agency), 2013. Reservation, http://tukes.fi/en/Branches/M ining/Reservation/ (accessed 17 June 2015).

Tuppurainen, T., 2012. 'Onko kaivosalalla malttia vaurastua'. Kaleva, 7 June, http://tytti.info/2012/06/08/onko-kaivosalalla-malttia-vaurastua/ (accessed 17 June 2015).

Walker, R.A., 2001. 'California's Golden Road to Riches: Natural Resources and Regional Capitalism, 18481940'. Annals of the Association of American Geographers, 91 (1): 167-199.

World Bank, 2010. World Development Report 2010. Washington, DC: The World Bank.

Wright, E.O., 2005. 'Foundations of a Neo-M arxist Class Analysis'. In Approaches to Class Analysis, ed. E.O. Wright, 4-30. Cambridge: Cambridge University Press. 